Gut, 1960, 1, 253.

\title{
BENIGN DUODENO-COLONIC FISTULA
}

\author{
BY \\ G. N. CHANDLER and A. J. LONGMORE \\ From the Department of Gastroenterology, Central Middlesex Hospital, London
}

\begin{abstract}
Two cases of benign duodeno-colic fistula are described. In the first, no cause was evident, but complete cure of an illness characterized by fatty diarrhoea, loss of weight, anaemia, and osteomalacia followed surgical repair. In the second patient cure was spontaneous after a peri-duodenal abscess from a perforated post-bulbar duodenal ulcer discharged into the hepatic flexure of the colon.
\end{abstract}

Duodeno-colic fistula is an uncommon lesion which usually results from the extension of carcinoma from the transverse colon. Benign causes of the condition are exceedingly rare and only 21 examples, of diverse aetiology, have been recorded since 1863 . The commonest single cause is peptic ulceration of the duodenum; McPeak (1940) presented two such cases, and single case reports were made by McClinton (1944), Railton (1948), Rife (1951), and Nash and Daland (1956).

The earliest recorded example is that of Sanderson (1863) who reported a patient with a fistula between the descending duodenum and the mid-transverse colon, probably the result of a perforating diverticulum of the duodenum. In a patient of Olson's, originally described by Krock (1950), the most likely cause of a fistula connecting the second part of the duodenum and the hepatic flexure of the colon was thought to be a diverticulum of the duodenum, and a third such case was reported by Winter (1959). Rees (1933) reported a fistula between the transverse colon and the duodenum just below the opening of the common bile duct, which had apparently arisen by the perforation of a typhoid ulcer 28 years previously. Ogilvie (1950) reported two cases of benign duodeno-colic fistula which appeared to have originated from a caseating tuberculous gland that had ulcerated simultaneously into the two viscera. Winfield (1951) recorded another example in which tuberculous lymphadenitis appeared to be the cause of a fistula between the third part of the duodenum and the sigmoid colon.

In three patients the condition occurred as a complication of ulcerative colitis. Ormandy and Bargen (1939) recorded the necropsy finding of multiple fistulae between the colon and the stomach and duodenum in a patient who died from ulcerative colitis. Ransom (1951) described two patients with colitis and fistulous connexions between the duodenum and transverse colon who made an uneventful recovery after subtotal colectomy and closure of the duodenum. Examples of the condition following attacks of acute cholecystitis were reported by Lovell (1947) and Neville (1954), and duodenocolic communications have been recorded in acute pancreatitis (Garland and Wyatt, 1951), in acute appendicitis (Clayton and Thornton, 1953), and in regional ileitis (Masters, 1948). Michell (1959) described a patient in whom the fistula developed after gastrectomy.

This paper reports two more examples of the condition. In one patient the clinical picture simulated that of the blind loop syndrome and is the first in which steatorrhoea has been recorded. The second patient presented as an acute abdominal emergency.

\section{CASE Reports}

CASE 10.-An unmarried woman, in comfortable circumstances, was aged 51 years at the time of her admission to the General Infirmary at Leeds in July, 1956. Seventeen years previously a diagnosis of pernicious anaemia had been made on the basis of a peripheral blood examination following a short history of diarrhoea with the passage of loose, pale stools and the constitutional symptoms of anaemia. She was unable to recall any episode of abdominal pain. She had been given regular injections of liver extract and more recently had been treated with vitamin B.12. Her health remained good until 1954 when she began gradually to lose energy and appetite; her weight fell by nearly $50 \mathrm{lb}$. $(22 \cdot 7 \mathrm{~kg}$.) in the ensuing two years. Diarrhoea again became troublesome with the passage of four or five loose, watery motions daily. Because of the development of pain about the knees and ankles associated with swelling of the feet and exertional dyspnoea she was referred to the Rheumatism Clinic and admitted under the care of Prof. S. J. Hartfall for further study. 


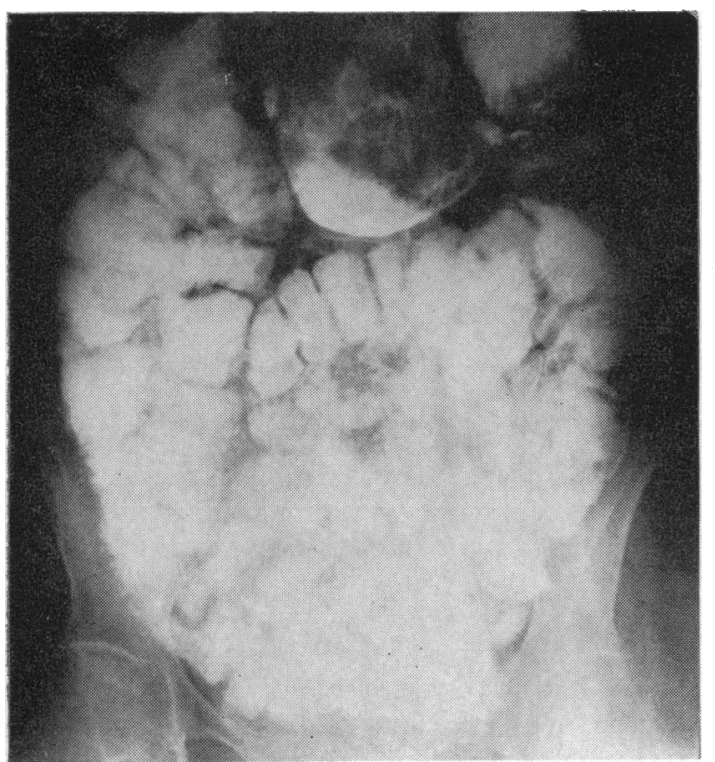

Fig. 1.-Barium enema examination (Case 1). Note presence of barium in the stomach.

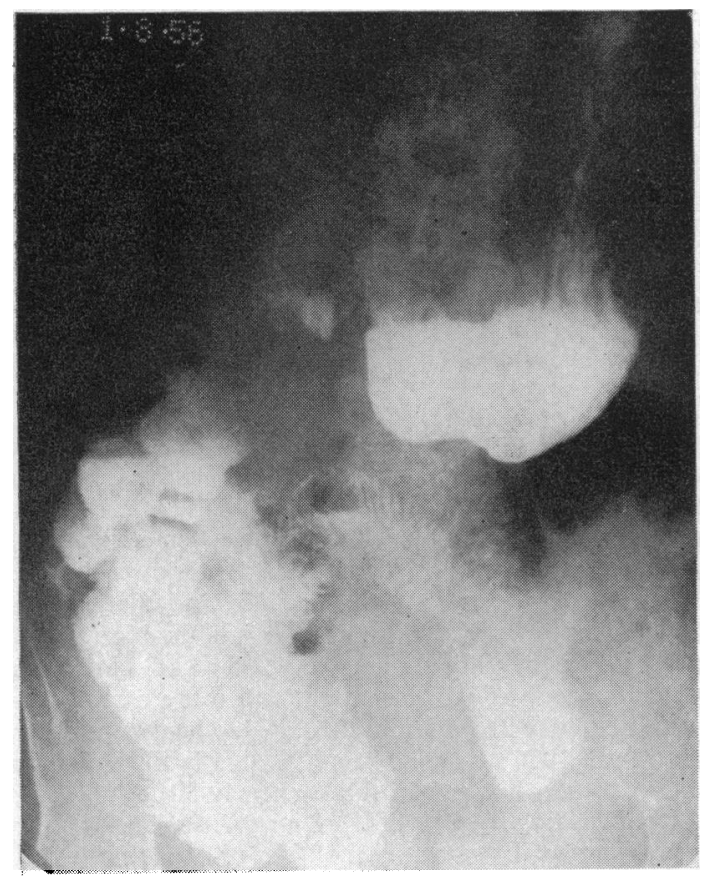

FIG. 2.-Barium meal examination (Case 2). Presence of fistula between duodenum and colon confirmed. The communication appears to arise at the outer border of the junction of the second and third parts.
Examination disclosed a thin but active woman. She was edentulous but the tongue and nails were normal. Both lower legs were oedematous and the skin showed pigmentation associated with superficial periphlebitis. The abdomen was distended and the liver and spleen enlarged two fingerbreadths below the costal margin. There was no neurological defect. The stools were loose, pale, and somewhat greasy.

Investigations gave the following results: haemoglobin $78 \%(11.5$ g. per $100 \mathrm{ml}$.); M.C.V. $97 \mathrm{cu}$, M.C.H.C. $31 \%$; colour index 1.0 ; white blood cells 4,500 per c.mm.; total serum proteins $6.2 \mathrm{~g}$. per $100 \mathrm{ml}$. (albumin $3.8 \mathrm{~g}$. and globulin $2.4 \mathrm{~g}$. per $100 \mathrm{ml}$.); gold sol negative; thymol turbidity 2 units; prothrombin time 14 seconds (control 13 seconds); serum calcium $8.1 \mathrm{mg}$. per $100 \mathrm{ml}$; serum phosphate $3.2 \mathrm{mg}$. per $100 \mathrm{ml}$; serum alkaline phosphatase 40 King-Armstrong units; serum sodium $139 \mathrm{mEq}$. per litre, serum potassium $3.6 \mathrm{mEq}$. per litre; serum chloride $109 \mathrm{mEq}$. per litre; plasma $\mathrm{CO}_{2} 21.5 \mathrm{mEq}$. per litre; sternal marrow puncture showed normoblastic erythropoiesis and normal levels of acid secretion were

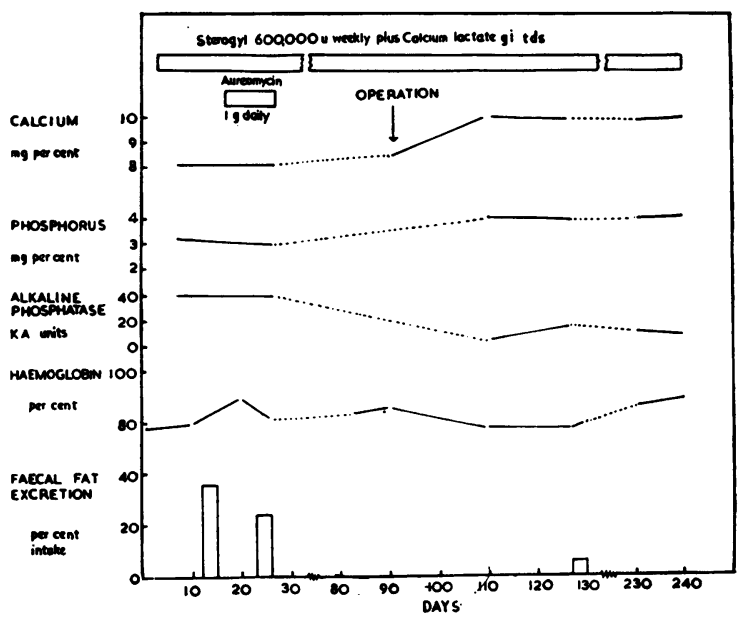

Fig. 3.-Effect of (a) chlortetracycline and (b) repair of the fistula on faecal fat excretion, haemoglobin percentage, and serum levels of calcium, phosphorus, and alkaline phosphatase in Case 1. During treatment with aureomycin faecal fat loss fell from $37 \%$ to $24 \%$ of dietary intake. Repair of the fistula abolished steatorrhoea, corrected the anaemia, and restored normal serum chemistry.

found by fractional test meal examination. A radiograph of the chest revealed only skeletal decalcification. A barium enema demonstrated the presence of a fistula between the duodenum and hepatic flexure of the colon (Fig. 1), which, on barium meal examination appeared to arise at the junction of the second and third parts of the duodenum (Fig. 2). A three-day fat balance study showed a faecal fat excretion of $37 \%$ of dietary intake.

Treatment with vitamin B.12 was stopped from admission but because of the evidence of osteomalacia she was given vitamin D ("sterogyl"), 600,000 units 
weekly by intramuscular injection, and calcium lactate, 1 g. t.d.s. During a period when chlortetracycline, 250 mg. q.d.s., was administered by mouth, a second fat balance study was made; this showed a reduction in faecal fat excretion to $24 \%$ of intake.

At operation in August, 1956, Professor J. C. Goligher found a fistula connecting the junction of the second and third parts of the duodenum with the hepatic flexure of the colon. There was no evidence of local disease and the remainder of the abdominal organs appeared healthy. Closure was easy and the patient's post-operative recovery was rapid and uneventful. The diarrhoea ceased entirely and a third fat balance study done two months after operation showed normal fat absorption (Fig. 3). The serum levels of calcium, phosphorus, and alkaline phosphatase also returned to normal and the limb pains disappeared. Within six months of operation the patient had gained $40 \mathrm{lb} .(18.2 \mathrm{~kg}$.) in weight and the treatment with calcium and vitamin D was discontinued. She has been reviewed at annual intervals and remains delighted with her sustained improvement.

This was an example of benign duodeno-colic fistula of at least 17 years' duration. No cause for its development could be demonstrated. The patient presented with diarrhoea of fatty type, considerable loss of weight, and osteomalacia. The

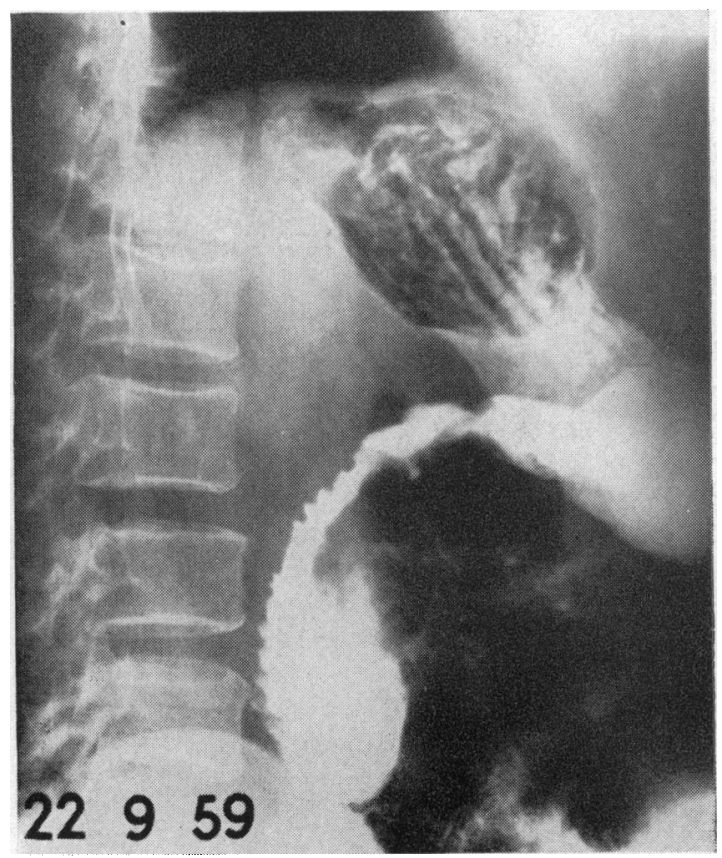

Fig. 4.-Barium meal examination (Case 2). The duodenal cap is somewhat deformed and immediately distal to it the upper two-thirds of the second part of the duodenum becomes grossly irregular in outline. Note ulcer crater on the concavity of the loop at the junction of the first and second parts of the duodenum.

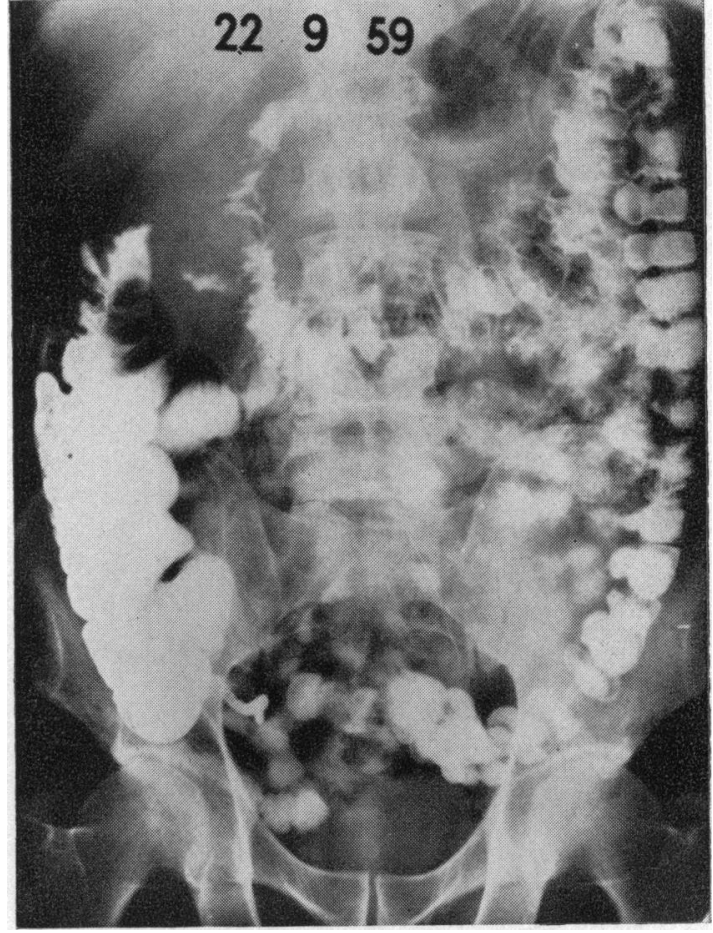

Fig. 5.-Barium meal examination (Case 2). Later film shows filling of the duodenum from the colon and $a$ collection of barium in a mass separating these two structures. Note shaggy outline of the hepatic flexure of the colon.

steatorrhoea was reduced by oral antibiotic treatment and abolished by repair of the fistula. Complete cure resulted from operation.

CASE 2.-A 58-year-old man of Anglo-Indian extraction was admitted to the Central Middlesex Hospital on September 12, 1959, because of abdominal pain. In 1939, he had been treated for amoebic dysentery in India; later that year he had developed dyspepsia of duodenal type and a diagnosis of duodenal ulcer had been made. With conventional medical treatment for his ulcer he had remained in excellent health until the day before admission when he took a purgative for constipation. Seven hours later he was seized with severe epigastric pain radiating into the right hypochondrium associated with the passage of loose, watery stools.

By the time of admission the pain had lessened and he did not seem acutely ill. His temperature was $100 \cdot 2^{\circ} \mathrm{F}$. and pulse rate 100 per minute. The abdomen was generally tense but nowhere rigid, and there was tenderness on palpation of the right upper quadrant. There was no other abnormality in any system. A plain film of the abdomen was normal, white cell count was 10,500 per c.mm., and bacteriological examination of the stools was negative. Sigmoidoscopy was normal to $25 \mathrm{~cm}$. 
During the first week of illness he complained of abdominal pain of no great severity and his temperature, at first intermittent, gradually rose to between $102^{\circ} \mathrm{F}$. and $103^{\circ} \mathrm{F}$. Diarrhoea meanwhile had lessened to average four loose motions daily without blood. On the eighth day after admission a firm, rounded mass could be felt in the right hypochondrium, and the white cell count had risen to 28,000 per c.mm. Liver function tests showed no abnormality except for a modest elevation of serum bilirubin to $1.5 \mathrm{mg}$. per $100 \mathrm{ml}$. Oral cholecystography showed no excretion of dye in the biliary system but barium meal examination on the tenth day of illness revealed a deformed duodenal cap with an ulcer crater just distal to it on the concavity of the loop at the junction of the first and second parts. The second part of the duodenum was compressed from its outer side and displaced forwards by a mass which was bounded superiorly by the right lobe of the liver. The hepatic flexure of the colon was grossly irregular in outline and lay on the outer side of the mass. In subsequent films there was a collection of barium in the mass, shown only in films in which the colon was outlined (Figs. 4 and 5).

Treatment with tetracycline, $250 \mathrm{mg}$. q.d.s., was begun 11 days after admission with prompt response; temperature fell to normal after 24 hours and the mass gradually diminished and finally disappeared within seven days, during which time the diarrhoea ceased. Subsequent re-examination by barium meal showed that the ulcer crater was still visible but no mass could be demonstrated and no escape of barium was seen.

The patient returned home one month after admission. He was active, ambulant, and afebrile. No abnormal physical signs remained and bowel function was normal.

This was an example of a benign duodeno-colic fistula consequent on the perforation of a postbulbar duodenal ulcer. The patient presented with an acute abdominal illness characterized by fever, diarrhoea, and abdominal pain. An inflammatory mass developed in the right sub-hepatic space which was shown to communicate with the colon by barium meal examination. Its subsequent discharge into the colon led to spontaneous cure.

\section{Discussion}

Of the various causes of benign duodeno-colic fistula performation of a duodenal ulcer is the most common, and is followed in frequency by ulcerative colitis and tuberculous lymphadenitis. In our first patient no cause was evident, but the situation of the fistula, which connected the junction of the second and third parts of the duodenum with the hepatic flexure, suggested the possibility that a foreign body might have been responsible. In the habit of making her own dresses she might have swallowed a needle or pin which, impacted at this particular curve of the duodenum, had gradually penetrated the colon and finally disappeared leaving only a fistulous track to mark its passage.

Diarrhoea is an almost inevitable sequel to the establishment of such a fistula, but in none of the reported cases with a benign aetiology has steatorrhoea been described. Mindline and Rosenheim (1935) reported an example of duodeno-colic fistula caused by carcinoma of the transverse colon in which the clinical picture simulated that of idiopathic steatorrhoea. It has long been recognized that any intestinal lesion causing stasis within the lumen of the gut as from stricture formation or by the production of a redundant loop of bowel could lead to the development of a syndrome characterized by diarrhoea, loss of weight, and macrocytic anaemia. Now known as the blind loop syndrome, the subject was reviewed by Cameron, Watson, and Witts (1949a). Of 61 patients, 24 had enteroanastomoses, nine of which were either gastro-colic or high jejuno-colic fistulas. Halsted, Lewis, and Gasster (1956) were able to collect 76 cases from the literature and added three of their own. Simple exclusion of a large part of the small intestine might be expected, on purely mechanical grounds, to lead to faulty absorption and a deficiency syndrome, but changes in the bacterial flora of the bowel are probably of greater significance. Cameron et al. (1949b) were able to produce a macrocytic anaemia in rats, sometimes associated with steatorrhoea, by fashioning blind loops in the small intestine. These intestinal cul-de-sacs were antiperistaltic and therefore self-filling to encourage stasis. In later work Watson and Witts (1952) showed that the anaemia so produced responded well to folic acid or chlortetracycline but poorly or not at all to vitamin B.12. In our patient (Case 1) evidence of bacterial interference with small intestinal function was obtained by giving aureomycin by mouth when faecal fat loss was reduced to almost half. It seems inescapable that bacterial colonization of parts of the intestine normally sterile is the basic cause of the syndrome, although the exact mechanisms involved are still far from clear (Badenoch, 1958). A change in the bacterial flora might condition vitamin deficiency in the host either by suppression of those organisms which synthesize vitamins or by the overgrowth of others which require the vitamins for their own metabolism. An abnormal bacterial population in the bowel may also be important in producing steatorrhoea, and Frazer (1949) has suggested that bacterial lipolysis of dietary fat may produce irritant fatty acids which are poorly absorbed and cause diarrhoea and the oversecretion of mucus.

Steatorrhoea, when it develops, leads to further nutritional disturbance by the impairment of absorption of fat-soluble vitamins, and this must be accepted as the probable explanation of the osteomalacia observed in our first patient. Certainly the 
theory that bacterial overgrowth in stagnant loops of bowel is chiefly responsible for the changes observed in the experimental anaemias in animals and the disease in man accords best with the facts. It seems unlikely that diversion of the intestinal contents per se is the sole or even the major cause of the illness in patients with entero-anastomoses. Barium meal examination usually demonstrates the preferential passage of the medium via the normal route; in many cases the fistula cannot be demonstrated by this means and barium enema study is by far the most successful method of diagnosis.

Though absorption can generally be improved with antibiotics and nutrition enhanced with a highcalorie, high-protein, low-fat diet with vitamin and mineral supplements, undoubtedly the treatment of choice in patients with the blind-loop syndrome is the restoration of the normal anatomy of the bowel. This is often impossible in cases where the lesions are multiple but in patients with gastro-colic, duodeno-colic, or jejuno-colic communications, simple repair of the fistula is usually strikingly successful.

Most benign duodeno-colic fistulas have been discovered during the course of investigation of patients with a long history of ill health characterized by diarrhoea and malnutrition. The duration of illness in the reported cases ranged from a few months to 23 years and only four patients gave a short history of acute ill health. Our second patient (Case 2) whose fistula was an almost immediate sequel to the perforation of a post-bulbar duodenal ulcer presented as an acute abdominal emergency. In this case the sequence of perforation, localized abscess formation, and eventual discharge into the colon provided the means of spontaneous cure. Such an event may occur more commonly than is recognized.

The symptoms of benign duodeno-colic fistula have a constancy of pattern which, without being typical, should arouse suspicion of its presence, particularly in patients with a history of duodenal ulceration. The most common symptom is loss of weight; on occasion this may be very great, as in the patient described by Ormandy and Bargen (1939) whose weight fell by $100 \mathrm{lb}$. Diarrhoea was a feature of all but two of the 14 cases reviewed by Clayton and Thornton (1953); vomiting occurred in seven and was faeculent in two. Clayton and Thornton comment on the surprising fact that only four patients mentioned the passage of undigested food with the stools and it is likely that more examples of malabsorption would be discovered if this possibility were to be borne in mind.
The recognition of benign duodeno-colic fistula is important because the therapeutic dividends are high. Its surgical correction can usually be accomplished quickly and easily and with it the patient is transformed from a state of chronic invalidism to one of full health unless the condition be part of a wider pathological process that requires its own special measures.

Ogilvie (1950) comments that the closure of a benign duodeno-colic fistula gives a surgeon the biggest return in gratitude with the least outlay of time and skill. We concur, and add only that on occasion nature may accomplish the same result.

We should like to thank Professor S. J. Hartfall and Professor J. C. Goligher for permission to publish the details of Case 1. The second patient was under the care of Dr. T. D. Kellock, and to him and to Dr. F. Avery Jones we are grateful for much helpful criticism.

\section{REFERENCES}

Badenoch, J. (1958). In Modern Trends in Gastro-Enterology, 2nd Ser. Ed. F. Avery Jones. p. 231. Butterworth, London.

Cameron, D. C., Watson, G. M., and Witts, L. J. (1949a). The clinical association of macrocytic anaemia with intestinal stricture and anastomosis. Blood, 4, 793.

- $(1949 \mathrm{~b})$. The experimental production of macrocytic anemia by operations on the intestinal tract. Ibid., 4, 803 .

Clayton, R. S., and Thornton, W. L. (1953). Benign duodenocolic fistula - Review of the literature and Case Report. Radiology, $60,832$.

Frazer, A. C. (1949). Fat metabolism and the sprue syndrome. Brit. med. J., 2, 769.

Garland, J. C., and Wyatt, K. (1951). Duodeno-colic fistula. Rocky Min med. J., 48, 426.

Halsted, J. A., Lewis, P. M., and Gasster, M. (1956). Absorption of radioactive vitamin B.12 in the syndrome of megaloblastic anemia associated with intestinal stricture or anastomosis. Amer. J. Med., $20,42$.

Krock, F. (1950) Discussion of Ogilvie. Ann. Surg., 131, 902.

Lovell, D. L. (1947). Internal biliary fistulas. Report of case. Sth. Surg., 13, 152.

Masters, H. (1948). Duodenal-colic fistula as a complication of regional ileitis. J. Mt Sinai Hosp., 15, 264.

McClinton, J. B. (1944). Non-malignant duodeno-colonic fistula. Canad. med. Ass. J., 51, 434.

McPeak, C. N (1940). Benign duodeno-colic fistula, with report of two Cases. Radiology, 34, 343.

Michell, R. C. (1959). Delayed post-operative duodeno-colic fistula. Brit. J. Radiol., 32, 55.

Mindline, J., and Rosenheim, M. L. (1935). Duodenocolic fistula simulating idiopathic steatorrhoea. Lancet, 2, 764

Nash, H. E., and Daland, E. M. (1956). Benign duodenocolic fistula. New Engl. J. Med., 254, 1032.

Neville, W. E. (1954). Duodenocolic fistula due to acute cholecystitis. Amer. J. Surg., $87,300$.

Ogilvie, H. (1950). Non-malignant duodeno-colic fistula. Report of two cases. Ann. Surg., 131, 899.

Ormandy, L., and Bargen, J. A. (1939). Thrombo-ulcerative colitis associated with cologastric and coloduodenal fistulas. Proc. Mayo Clin., 14, 550.

Railton, S. V. (1948). Benign duodeno-colic fistula. Canad. med. Ass., J., 59, 267.

Ransom, H. K. (1951). Discussion of Rife. A.M.A. Arch. Surg.,

Rees, C. E. (1933). Duodenocolic fistula with incompetent sphincter of Oddi. J. Amer. med. Ass., 100, 496.

Rife, C. S. (1951). Benign duodenocolic fistula. A.M.A. Arch. Surg., $62,876$.

Sanderson, J. R. (1863). Duodeno colic fistula. Trans. path. Soc. Lond 14,173 .

Watson, G.' M., and Witts, L. J. (1952). Intestinal macrocytic anaemia., Brit. med.J., 1, 13.

Winfield, J. M. (195i). Discussion of Rife. A.M.A. Arch. Surg., 62,882 .

Winter, J. (1959). Benign duodenocolic fistula. J. Fac. Radiol. (Lond.), 10, 221. 